\title{
PENGARUH PEMBERIAN JUS BUAH NANGKA MATANG (Artocapus heterophyllus) PADA TIKUS BUNTING (Rattus norvegicus strain wistar) TERHADAP KEJADIAN BBLR
}

\author{
Dea Pradipta ${ }^{1 *}$, Nurdiana ${ }^{2}$, Ni Luh PutuHerli Mastuti ${ }^{2}$ \\ "S1 Kebidanan Fakultas Kedokteran Universitas Brawijaya \\ Email* : ddeapradipta@gmail.com \\ HP : +6281333199686
}

\begin{abstract}
According Balitbangkes and Kemenkes RI (2013) in Indonesia the percentage of Low Birth Weight (LBW) occurrence in 2013 reached 10.2\%. One of the causes is the Alcohol Consumption Pattern During Pregnancy, the high glucose levels present in the jackfruit can potentially be a source of alcohol. The purpose of this research is to see the effect of juice of jackfruit fruit to the occurrence of Low Birth Weight (LBW) in rat fetus. The design of this study using pure experimental with Post Test Design Design Only Control Group Design. Using 20 female pregnant ratstype Rattus norvegicus strains wistar and divided into 4 groups, namely; control (P0), Treatment $1(P 1)=0.85$ $\mathrm{ml} / 200 \mathrm{~g} \mathrm{BB} /$ day, Treatment $2(\mathrm{P} 2)=1.7 \mathrm{ml} / 200 \mathrm{~g} \mathrm{BB} /$ day and Treatment $3(\mathrm{P} 3)=3.4 \mathrm{ml} / 200 \mathrm{~g}$ BB /day) Jackfruit juice was given for 19 days and on the 19th day the mouse was dissected and the fetus was taken to be weighed. Obtained results in group P0 mean fetal weight of mouse $4.18 \pm$ $1.39 \mathrm{gr}$, group $\mathrm{P} 1=3.60 \pm 1.15 \mathrm{gr}$, group $\mathrm{P} 2=3.56 \pm 0.57 \mathrm{gr}$, and in group $\mathrm{P} 3=2.84 \pm 1.80 \mathrm{gr}$. Analysis of Oneway Anova got result pvalue $=0,475(p>0,05)$ It is said that fetal weight loss in group P1, P2 and P3 did not differ significantly with group P0. However, there is a downward trend in rat fetal weight with increasing doses of a given fruit juice jackfruit.
\end{abstract}

Keywords: birth weight, jackfruit juice, alcohol, pregnant mice

\begin{abstract}
ABSTRAK
Menurut Balitbangkes dan Kemenkes RI (2013) di Indonesia persentase kejadian Berat Badan Lahir Rendah (BBLR) pada tahun 2013 mencapai 10,2\%dan salah satu penyebabnya yaitu Pola Konsumsi Alkohol Selama Kehamilan. Tingginya kadar glukosa yang ada pada buah nangka matang berpotensi menjadi sumber alkohol. Tujuan dari penelitian ini yaitu untuk melihat adanya efek jus buah nangka matang terhadap kejadianBerat Badan Lahir Rendah (BBLR) pada janin tikus. Desain penelitian ini menggunakan eksperimental murni dengan rancangan penelitian Post Test Only Control Group Desain. Menggunakan 20 ekor tikus betina bunting jenis Rattus
\end{abstract}


norvegicus strain wistar dan dibagi menjadi 4 kelompok, yaitu; kontrol (P0), Perlakuan $1(P 1)=0,85$ $\mathrm{ml} / 200 \mathrm{~g} \mathrm{BB} /$ hari, Perlakuan 2 (P2) = 1,7 ml/200g BB/hari dan Perlakuan 3 (P3) = 3,4 ml/200g $\mathrm{BB} /$ hari). Jus buah nangkadiberi selama 19 hari dan pada hari ke-19 tikus bunting dibedah lalu diambil janinnya untuk ditimbang. Didapatkan hasilnya pada kelompok P0 rata-rata berat badan janin tikus4.18 $\pm 1.39 \mathrm{gr}$, kelompok P1=3.60 $\pm 1.15 \mathrm{gr}$, kelompok P2 $=3.56 \pm 0.57 \mathrm{gr}$, dan pada kelompok P3 $=2.84 \pm 1.80 \mathrm{gr}$. Analisis Oneway Anova didapatkan hasil pvalue $=0,475(p>0,05)$ dikatakan penurunan berat badan janin tikus pada kelompok P1, P2 dan P3 tidak berbeda signifikan dengan kelompok P0. Akan tetapi ada kecenderungan penurunan berat badan janin tikus dengan peningkatan dosis jus buah nangka yang diberikan.

Kata kunci: berat badan lahir rendah, jus buah nangka, alkohol, tikus bunting

*Korespondensi: Dea Pradipta. Surel: ddeapradipta@gmail.com 


\section{PENDAHULUAN}

Berat Badan Lahir Rendah (BBLR) merupakan berat badan bayi baru lahir dengan yang kurang darii 2.500 gram tanpa memandang masa gestasinya (Tando,2016). Sedangkan menurut survei yang dilakukan oleh Balitbangkes dan Kemenkes RI (2013) di Indonesia sendiri persentasee kejadian BBLR tahun 2013 mencapai 10,2\%, yang dimana satu dari sepuluh bayi di Indonesia mengalami BBLR. Sebagian besar penyebab utama dari BBLR adalah gangguan gizi yang terjadi pada ibu hamil. Kebiasaan makan pada ibu hamil sangat dipengaruhi oleh lingkungan dan konsepsi budaya sekitar tempat tinggalnya. Beberapa penelitian yang dilakukan di dunia menemukan bahwa ibu hamil merupakan salah satu kelompok risiko tinggi kekurangan gizi akibat tabu makanan atau pantangan makan. Salah satunya yaitu kepercayaan dilarang memakan buah nangka karena dipercaya mengandung pewangi yang dapat membahayakan kehamilan.

Sedangkan buah nangka merupakan salah satu jenis buah tropis yang multifungsi dan dapat ditanam pada daerah tropiis. Tingginya kadar glukosa yang ada pada buah nangka matang, berpotensi menjadi sumber alkohol melalui sebuah proses fermentasi secara alami (Fachruddin,2002). Dalam penelitian yang dilakukan Wong, et all pada tahun 1992, menyatakan bahwa terdapat 31,9\% kadar konsetrasi alkohol di buah nangka matang (Baliga,2011). Alkohol merupakan salah satuzat yang sangat berbahaya jika dikonsumsi ibu hamil selama kehamilan, dimana salah satunya dapat menyebabkan berat badan lahir rendah pada bayi yang dilahirkan. Pernyataan ini didukung oleh penelitian yang telah dilakukan olehNykjaer, et al (2014), mereka menyatakan bahwa ibu hamil yang mengkonsumsi alkohol sebanyak 14 gram per minggu pada trimester satu maka didapatkan $4,4 \%$ bayi yang dilahirkan mengalami Berat Badan Lahir Rendah lalu 4,3\% mengalami prematur.

Maka denganini peneliti tertarik untuk meneliti apakah buah nangka matang yang mengandung alkohol, dapat mengakibatkan terjadinya Berat Badan Lahir Rendah (BBLR) pada janin Tikus.

\section{METODE PENELITIAN Rancangan Penelitian}

Pada penelitian ini, peneliti menggunakan desain experimental murni dan rancangann penelitian menggunakan Post Test Only Control Group Desain yaitu akan membandingkan hasiil antara kelompok yang sudah diberii perlakuan (post test) dengan kontrol.

\section{Sumber Data}

Penelitian ini bertempatkan di Laboratorium Farmakologi Fakultas Kedokteran Universitas Brawijaya. Lamanya waktu yang diperlukan untuk melakukan penelitian yaiitu mulai November 2017- Januari 2018

\section{Sampel Penelitian}

Populasi yang digunakan dalam pnelitian ini yaitu tikus Rattus norvegius strain wistar.Sampel yang 
digunakan berupa tikus Rattus norvegicus strain wistar betina bunting sebanyak 20 ekor dengan berat masing-masing tikus $180-250$ gram. Tikus dalam kondisi sehat, bulu berwarna putih, tidak rontok dan bersih, bergerak lincah, dan tidak cacat.

\section{Teknik Analisis Data}

Data penelitian ini dianalisis menggunakan progrram SPSS 12.0 for windows dengan menggunakan metode Uji One Way Anova $(p<$ 0,05 ). Sebelumnya, lakukan uji normalitas Shapiro-Wilk dan uji homogenitas untuk memastikan persebarann datanya. Lalu lakukan uji One way Anova untuk melihat pengaruh jus buah nangka terhadap berat lahir janin tikus di waktu yang bersamaan. Dilanjutkann dengan Uji Post $\operatorname{Hoc}(\mathrm{p}<0,05)$ dan uji korelasi Pearson.

\section{HASIL PENELITIAN}

Pada tabel 1, menunjukkan pada kelompok kontrol memiliki rata-rata berat badan janin tikus $4.18 \pm 1.39$ gram. Pada kelompok perlakuan $1(\mathrm{P} 1)=3.60 \pm 1.15$ gram, sedangkan pada kelompok perlakuan $3(\mathrm{P} 3)=2.84 \pm 1.80$ gram. Pada pengamatan berat badan janin tikus menunjukkan bahwa peningkatan dosis pemberian jus buah nangka selama kehamilan pada induk tikus cenderung menyebabkan terjadinya penurunan berat badan janin tikus.
Berdasarkan

Gambar.1, terdapat kecenderungan penurunan berat badan janin tikus dengan peningkatan dosis jus buah nangka yang diberikan. Penurunan berat badan janin tikus terendah terdapat pada kelompok perlakuan 3 (P3) yang diiberikan dosis $3,4 \mathrm{ml} / 200 \mathrm{~g}$ BB/hari. Perbedaan rata-rata penurunan berat badan janin tikus antar kelompok, masuk dalam kelompok a atau masuk pada kolom 1 diuji Homogeneous Subsets, yang berarti tidak terdapat perbedaan penurunan berat badan janin tikus yang signifikan antar kelompok satu dan kelompok lainnya.

Hasil dari uji One Way Anova didapatkan nilai $p$ value $=0,475$ ( $p$ > 0,05 ) maka dikatakan penurunan berat badan janin tikus pada kelompok P1, P2 dan P3 tidak berbeda signifikan dengan kelompok P0. HasildariUji Post Hoc didapatkan perbedaanantara kelompok kontrol (P0) dan P3 dengan nilai 0,399 ( $p>0,05)$. Maka hasil AnalisisUji Post Hoc tidak terdapat kelompok yang berbeda secara signifikan.

Sedangkan untuk hasil uji korelasi, didapatkan hasil - 0,358 $(p<0,5)$ yang berarti terdapat hubungan yang lemah dan berlawanan arah, sehingga semakin tinggi dosis jus buah nangka yang diberikan maka semakin rendah berat badan janin tikus. 
Tabel 1. Hasil pengamatan rata-rata berat badan janin tikus

\begin{tabular}{|c|c|c|}
\hline \multirow{2}{*}{ No. } & KelompokPerlakuan & $\begin{array}{c}\text { Rata-rata berat badan janin tikus } \\
\text { (gram) }\end{array}$ \\
\cline { 3 - 3 } & & Mean \pm SD \\
\hline 1. & Kontrol (P0) & $4.18 \pm 1.39$ \\
\hline 2. & Perlakuan 1 (P1) & $3.60 \pm 1.15$ \\
\hline 3. & Perlakuan 2 (P2) & $3.56 \pm 0.57$ \\
\hline 4. & Perlakuan3 (P3) & $2.84 \pm 1.80$ \\
\hline
\end{tabular}

*Uji One Way Anova

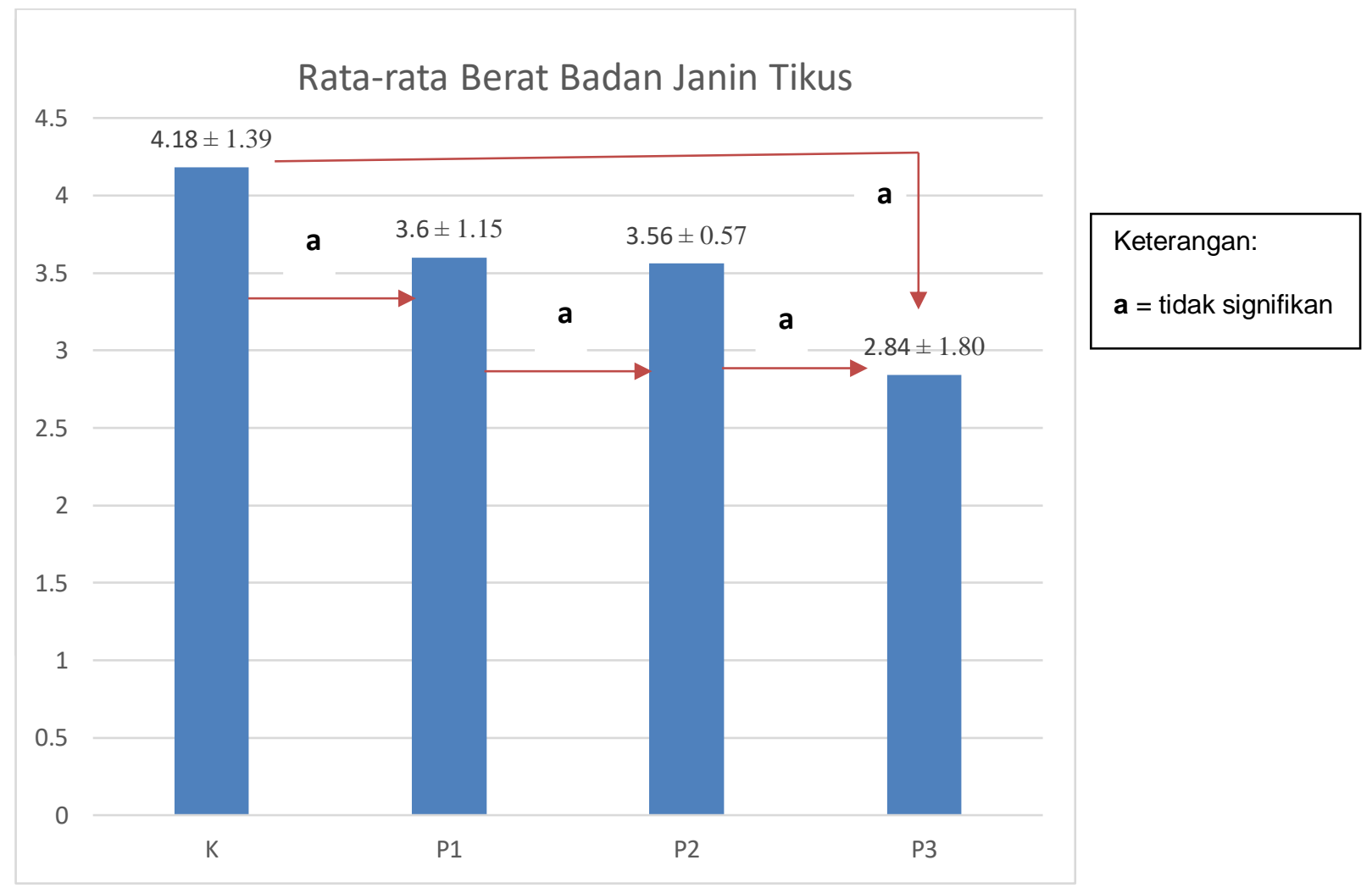

Gambar 1. Grafik Rata-rata Berat Badan Janin Tikus 


\section{PEMBAHASAN}

Pada penelitian ini, pemilihan hewan coba menggunakan tikus putih jenis Rattus norvegicus betina bunting, sesuai dengan kriteria inklusi yaitu tikus yang sehat, bergerak aktif, bulu tebal berwarna putih dan usia 8-12 minggu. Menggunakan 20 ekor tikus yang dibagi menjadi 4 kelompok perlakuan secara acak. Pada kelompok kontrol tidak diberi paparan jus nangka, sedangkan pada kelompok perlakuan 1 diberikan dosis jus nangka sebesar 0,85 $\mathrm{ml} / 200 \mathrm{~g}$ BB/hari, kelompok perlakuan 2 diberikan dosis 1,7 $\mathrm{ml} / 200 \mathrm{~g}$ BB/hari, dan kelompok perlakuan 3 diberikan dosis 3,4 $\mathrm{ml} / 200 \mathrm{~g} B \mathrm{~B} /$ hari. Buah nangka yang sudah disimpan di dalam lemari es selama 3 hari diperas dan diambil airnya, lalu air nangka diberikan setiap hari selama 19 hari per oral menggunakan sonde lambung. Pada hari ke-19, dilakukan pembedahan pada induk tikus untuk diambil janinnya, lalu dilakukan penimbangan berat badan janin tikus menggunakan neraca analitik

Penelitian ini menggunakan buah nangka yang dipercaya pada budaya tertentu sebagai pantangan untuk diikonsumsi oleh ibu hamil karena dapat menyebabkan keguguran dan memiliki pewangi yang berbahaya bagi kehamilan (Anggraini, 2013; Sholiha, 2014). Pernyataan tersebut juga didukung oleh penelitian yang dilakukan oleh Prasetyo (2015), dimana peneliti menyatakan tingginya kandungan glukosa yang terdapat pada buah nangka matang berpotensi untuk dijadikan sumber alkohol. Terbukti dari hasil penelitiannya yang menunjukkan, kadar alkohol pada sampel buah nangka matang
(Artocarpus

heterophyllus

Lamk)mengalami peningkatan pada hari ke-3 selama penyimpanan sebesar $24,322 \%$. Sedangkan pada penelitian yang dilakukan oleh Fatimah, et al (2013) menyatakan bahwa jus buah salak yang didiamkan selama 72 jam didalam suhu $30^{\circ} \mathrm{C}$ menghasilkan etanol sebesar 2,96 $\mathrm{gr} / \mathrm{ml}$.

selama kehamilan dikonsumsi membahayakan kondisi ibu dan meningkatkan kejadian berat badan lahir rendah pada bayinya. Dari sebuah penilitian yang dilakukan oleh Mariscal, et al (2006) didapatkan bahwa kelompok ibu yang mengkonsumsi alkohol 12 $\mathrm{g} /$ hari meningkatkan terjadinya kejadian Berat Badan Lahir Rendah (BBLR) pada bayi yang dilahirkannyaa.

Pada penelitian ini didapatkan air nangka sebanyak 0,96 gram mengandung etanol 0,25 gram dengan konsentrasi 0,58\% dari hasil fermentasi alami yang terjadi pada buah nangka saat disimpan selama 3 hari di dalam lemari es. Maka pemberian jus buah nangka pada hewan coba, menggunakan dosis awal 0,85 $\mathrm{ml} / 200 \mathrm{~g}$ BB/hari setara dengan pemberian alkohol $12 \mathrm{~g} / \mathrm{hari}$ pada manusia. Dari hasil penelitian ini, membuktikan bahwa jus buah nangka yang diberikan pada tikus bunting sudah dapat mengakibatkan kejadian berat badan lahir rendah pada janin tikus. Akan tetapi secara statistik perbedaan penurunan berat badan janin tikus antar kelompok perlakuan (P1, P2 dan P3) dan kontrol dinyatakan tidak signifikan $p$ value $=0,475(p>0,05)$. 
Hasil dari penelitian ini didukung dengan penelitian yang dilakukan oleh Mariscal, et al (2006) yang menyatakan bahwa pemberian alkohol pada tikus bunting dengan dosis 1-2 $\mathrm{gr} / \mathrm{kg}$ belum dapat menyebabkan kejadian berat badan lahir rendah pada janin tikus yang dilahirkan. Berbanding terbalik dengan penelitian yang dilakukan oleh Abel (1995) yang menunjukkan, terdapat penurunan berat badan janin yang signifikan pada pemberian dosis alkohol sebesar 3,0 gr/kg pada tikus bunting. Pemberian alkohol dilakukan pada hari ke-8 sampai hari ke-20 kehamilan, pada saat itu terjadi masa organogenesis, dimana masa pertumbuhan dan perkembangan tubuh janin yang akan terganggu.

Maka dapat disimpulkan perbedaan waktu saat pemberian paparan diduga menjadi penyebab berbedanya kepekaan terhadap zat yang diberikann dan pada penelitian ini diperlukan dosis awal yang lebih tinggi untuk dapat diinyatakan penurunan berat badan janin tikus signifikan.

Hasil dari penelitian ini yaitu mengkonsumsi jus buah nangka dengan dosiss awal 0,85 $\mathrm{ml} / 200 \mathrm{gBB} /$ hari pada tikus buntiing, tidak menimbulkan efek yang membahayakan pada janin tikus. Namun, diperlukan penelitian lebih lanjut untuk memastikan apakah tidak ada efek yang membahayakan jika pada manusia. Keterbatasan penelitian ini adalah kurangnya jumlah tikus yang digunakan dan pelaksanaan prosedur penghamilan tikus yang kurang tepat, sehingga tidak semua tikus dapat bunting secara bersamaan
PEMBAHASAN

\section{Hubungan antara Usia dengan Tingkat Pengetahuan tentang Tanda Bahaya Kehamilan}

Pada penelitian saat ini, karakteristik usia pada ibu hamil dibagi menjadi 2 kategori, yaitu usia reproduksi sehat (usia 20-35 tahun) dan usia reproduksi tidak sehat (usia <20 tahun atau >35 tahun). Hasil penelitian di BPM Sumidyah Ipung menunjukkan bahwa rata-rata usia ibu paling banyak dalam kategori usia reproduksi sehat sebanyak 23 orang (71,9\%). Usia dapat menstimulasi pena laran dan daya tangkap seseorang. Jika usia ibu semakin bertambah, maka penalaran dan daya tangkapnya akan semakin tumbuh dan berkembang. Hal tersebut merupakan hal positif jika banyak ibu yang hamil dalam kategori usia reproduksi sehat dengan batasan usia 20-35 tahun, yang menunjukkan adanya peningkatan kesadaran para ibu dalam merencanakan kehamilannya jika dilihat dari segi usia ${ }^{11}$.

Hasil analisis data didapatkan nilai $p$ value 0,000 yang berarti signify kan pada hubungan antara usia de ngan tingkat pengetahuan ibu tentang tanda bahaya kehamilan karena nilai $p$ value kurang dari 0,05 . Hasil tersebut membuktikan bahwa terdapat hubu ngan yang signifikan antara usia ibu dengan tingkat pengetahuan tentang tanda bahaya kehamilan. Penelitian ini sesuai dengan penelitian yang menunjukkan bahwa ada hubungan antara usia dengan tingkat pengetahuan tentang tanda bahaya kehamilan dengan nilai 0,017 $(p<0,05)^{12}$. Hasil penelitian lainnya dari Astuti (2011) juga menunjukkan ada hubungan yang signifikan ada 
hubungan antara usia dengan tingkat pengetahuan tentang tanda bahaya kehamilan dengan nilai $0,001 \quad(p<0,05)^{13}$. Penelitian ini sesuai dengan penelitian yang pernah dilakukan oleh Sukesih (2012) yang menun jukkan bahwa ibu hamil yang berusia 20-35 tahun (usia reproduksi sehat) berpeluang 7,3 kali untuk mempunyai pengetahuan lebih baik mengenai tanda bahaya kehamilan dibandingkan dengan yang berusia $<20$ tahun atau $>35$ tahun $^{14}$.

Semakin bertambah usia maka semakin bertambah pula daya tangkap dan pola pikirnya sehingga pengetahuan yang diperolehnya semakin baik. Namun beberapa teori berpendapat bahwa pada usia tertentu, kemampuan memahami dan menginngat pengetahuan akan berkurang. Beberapa teori ber pendapat tidak dapat mengajarkan kepandaian baru kepada orang yang sudah tua karena mengalami kemundu ran baik fisik maupun mental. Jadi dapat diperkirakan bahwa IQ akan menurun sejalan dengan bertambahnya usia ${ }^{1}$.

Seseorang yang hamil saat berusia masih muda mempunyai daya tangkap yang baik ketika memperoleh suatu informasi ataupun pengetahuan teraktual dan baru. Tetapi jika usianya kurang dari dua puluh tahun yang tergolong masih sangat muda mempunyai kesiapan yang kurang dalam mengatasi dan merawat dirinya sendiri ataupun janin yang dikandungnya sehingga seringkali terlalaikan penjagaan dalam menjalani masa kehamilannya ${ }^{14}$.

$$
\text { Menurut }
$$

Rogers, menerangkan bahwa usia yang lebih muda mempu nyai kemampuan lebih cepat dalam menerima inovasi baru. Tetapi, usia yang terlalu muda (<20 tahun) belum mempu nyai kesiapan secara fisik dan psikologis dalam menghadapi kehamilan, sehingga perawatan selama kehamilan sering terabaikan, karena tidak adanya keinginan untuk mencari pengetahuan mengenai kehamilannya. Sedangkan usia terlalu tua (> 35 tahun) bisa merasa bahwa dirinya telah terlatih dan mempunyai pengalaman yang lebih sehingga menjadikan ibu hamil tersebut kurang mempunyai kemauan dalam mendapatkan informasi-informasi yang baru seputar kehamilannya ${ }^{14}$. Disisi lain, seseorang yang usianya lebih dari 35 tahun akan mengalami penurunan kemampuan dalam menerima suatu informasi ataupun pengetahuan karena faktor semakin bertambahnya usia. Pada usia > 35 tahun, fungsi organ reproduksi mengalami penurunan sehingga dapat menambah resiko terjadinya kegawatdaruratan dan komplikasi seperti persalinan lama, perdarahan dan cacat bawaan ${ }^{12}$. Sehingga pada hasil penelitian ini sesuai dengan pernyataan bahwa usia dapat mempengaruhi daya tangkap dan pola pikir seseorang ${ }^{1}$.

Hubungan antara Pendidikan dengan Tingkat Pengetahuan tentang Tanda Bahaya Kehamilan Pendidikan menggambarkan suatu usaha dalam meningkatkan atau pun memperbaiki potensi kemampuan dalam berpikir manusia untuk lebih bisa maju dan berkembang dalam menjalani kehidupan. Pada penelitian ini, pendidi kan dibagi menjadi dua kategori, yaitu pendidikan rendah dan pendidikan tinggi. Sebagian 
besar responden memiliki tingkat pendidikan tinggi sebanyak 20 orang $(62,5 \%)^{14}$.

Pendidikan merupakan suatu upaya meningkatkan sumber daya manusia berkualitas yang dapat mem pengaruhi orang lain baik individu, kelompok dan masyarakat. Tingginya tingkat pengetahuan akan mempe- ngaruhi upaya pencegahan dan kesadaran akan perlunya sikap untuk hidup sehat ${ }^{12}$. Pendidikan mempunyai kekuatan untuk mempengaruhi penalaran atau pola pikir seseorang sehingga dapat mendewasakan seseorang melalui suatu usaha dalam bentuk pelatihan ataupun pengajaran baik pada jenjang pendidikan formal ataupun informal. Untuk jenjang pendidikan formal bisa diartikan sebagai suatu bentuk penyampaian ilmu berupa materi yang diberikan oleh para pendidik kepada para anak didiknya. Pendidikan dapat mempengaruhi persepsi seseorang dalam mengambil keputusan dan bertindak ${ }^{14}$.

Dalam penelitian ini menunjukkan bahwa hasil uji statistik antara pendidikan dengan tingkat pengetahuan menunjukkan nilai $p$ value $=0,037$ yang berarti signifikan karena $p$ value $<0,05$. Hasil tersebut membuktikan bahwa ada hubungan antara pendidikan ibu dengan tingkat pengetahuan tentang tanda bahaya kehamilan. Penelitan ini sesuai dengan penelitian yang pernah dilakukan oleh Sulyani (2013) yang menunjukkan bahwa ada hubungan antara pendidikan dengan tingkat pengetahuan tentang tanda bahaya kehamilan dengan nilai 0,007 $(p<0,05)^{8}$. Hasil penelitian lainnya dari Astuti (2011) juga menunjukkan ada hubungan yang signifikan ada hubungan antara pendidikan dengan tingkat pengetahuan tentang tanda bahaya kehamilan dengan nilai $0,001 \quad(p<0,05)^{12}$. Penelitian lainnya juga memberikan kesimpulan bahwa ada hubungan antara pendidikan dengan tingkat pengetahuan tentang tanda bahaya kehamilan dengan nilai 0,015 $(p<0,05)^{15}$. Ibu hamil yang berpendidikan tinggi berpeluang 8,1 kali mempunyai pengetahuan lebih baik mengenai tanda bahaya kehamilan dibandingkan dengan ibu hamil yang berpengetahuan rendah ${ }^{14}$.

Pendidikan merupakan pemicu utama kemauan seorang ibu hamil untuk mencari tahu tentang tandatanda bahaya kehamilan ${ }^{23}$. Pendidikan akan berpengaruh terhadap cara berfikir dalam pengambilan keputusan seseorang untuk menggunakan pela yanan kesehatan, maka semakin tinggi pendidikan ibu akan semakin baik pula pengetahuan kesehatan. Tingkat pendi dikan yang tinggi mempunyai pengaruh yang baik dalam mempermudah ibu hamil untuk menerima informasi-infor masi yang baru karena bisa lebih cepat memahaminya. Semakin tinggi tingkat pendidikan maka diharapkan semakin baik pula pengetahuan ibu hamil dalam mengenal dan memahami tanda bahaya kehamilan. Ibu dan keluarga dapat lebih mudah mengenali tanda bahaya kehamilan yang muncul dan menerapkan respon yang cepat untuk segara ke tenaga kesehatan jika terjadi tanda bahaya kehamilan ${ }^{12}$. Sedangkan pendidikan rendah walaupun sudah ada sarana yang baik namun belum tentu dipergunakan, hal ini disebabkan seorang pendidikan rendah tidak 
peduli terhadap program kesehatan sehingga tidak mengenal bahaya yang mungkin terjadi ${ }^{15}$.

Tingkat pendidikan dapat mempengaruhi daya pikir seseorang untuk dapat menerima segala informasi dari lingkungan sekitarnya ${ }^{14}$. Pendidi kan yang tinggi atau baik dapat mem perluas ilmu pengetahuan ibu hamil. Ibu hamil yang berpendidikan tinggi mempunyai kepedulian yang lebih besar dalam menjaga kehamilannya terutama untuk mengetahui tanda bahaya kehamilan sebagai upaya mencegah timbulnya komplikasi dalam kehamilan. Sementara itu, jika seorang ibu hamil yang mempunyai pendidikan rendah maka dapat mengakibatkan terhambatnya atau kurangnya penge tahuan atau informasi yang bisa di peroleh pada tingkat pendidikan yang lebih tinggi ${ }^{12}$. Jadi, semakin tinggi pendidikan maka akan semakin mudah seseorang dalam menerima informasi sehingga lebih mudah untuk mening katkan pengetahuannya tentang tanda bahaya kehamilan ${ }^{14}$.

\section{Hubungan antara Pekerjaan dengan Tingkat Pengetahuan tentang Tanda Bahaya Kehamilan}

Bekerja merupakan aktivitas pokok yang dilakukan dengan rutin untuk menunjang kebutuhan rumah tangga. Status pekerjaan akan memudahkan untuk mendapatkan pelayanan kesehatan, ibu hamil tetap bekerja dan tidak merubah pola bekerja sehari-hari ${ }^{15}$. Untuk keperluan analisis data, pekerjaan dideskripsikan dengan kategori bekerja dan tidak bekerja. Pada penelitian saat ini membuktikan bahwa sebagian besar ibu hamil memilih untuk tidak bekerja yaitu sebanyak 18 ibu (56,2\%). Hal tersebut menjelaskan bahwa sebagian besar ibu hamil menjalani perannya secara penuh sebagai seorang istri yang mengurus segala keperluan rumah tangga dan sebagai ibu yang mengasuh dan mendidik anaknya. Dalam sebuah keluarga biasanya terdapat pembagian peranan,dimana seorang suami sebagai kepala keluarga mempunyai tugas mencari nafkah untuk kebutuhan hidup sehari-hari, sedangkan seorang istri sebagai pengurus segala keperluan rumah tangga dalam keluarganya ${ }^{12}$. Hasil uji statistik antara pekerjaan dengan tingkat pengetahuan menunjukkan nilai $p$ value $=0,028$ yang berarti signifikan karena $\mathrm{p}$ value $<0,05$. Hasil tersebut membuktikan bahwa ada hubungan antara pekerjaan ibu dengan tingkat pengetahuan tentang tanda bahaya kehamilan. Sebagian besar ibu hamil tidak bekerja artinya mereka mempunyai waktu yang cukup banyak yang dapat digunakan untuk mencari informasi seputar kehamilan sehingga pengetahuanya menjadi baik ${ }^{6}$.Namun, tidak semua ibu yang tidak bekerja mempunyai waktu luang untuk mendapatkan informasi. Hal ini mungkin dikarenakan ibu cenderung untuk mengurusi urusan rumah tangga. Selain itu, hal ini juga bergantung pada keinginan ibu untuk mendapatkan informasi tersebut ${ }^{3}$.

Wanita seringkali meneruskan bekerja selama kehamilan. Jenis pe erjaan, tingkat aktivitas fisik, risiko lingkungan atau bahaya pekerjaan, dan masalah obstetri atau medis wanita mempengaruhi apakah dan berapa lama dia harus melanjutkan bekerja 
selama kehamilan. Jika tidak ada faktor risiko, kerja tidak meningkatkan komplikasi di akhir kehamilan, kelahiran prematur, atau kelahiran bayi berat lahir rendah ${ }^{9}$. Hal-hal yang perlu diperhatikan dalam pekerjaan atau aktivitas bagi ibu hamil adalah apakah aktivitasnya berisiko bagi kehamilan. Contoh aktivitas yang berisiko bagi ibu hamil adalah aktivitas yang meningkatkan stress, berdiri lama sepanjang hari, mengangkat sesuatu yang berat, paparan terhadap suhu atau kelembaban yang ekstrim tinggi atau rendah, pekerjaan dengan paparan radiasi ${ }^{14}$. Wanita menghadapi banyak tuntutan di rumah dan di tempat kerja yang dapat menciptakan konflik peran. Rata-rata wanita di seluruh dunia bekerja 80 jam setiap minggu di rumah dan di tempat kerja. Sedangkan rata-rata pria bekerja 50 jam setiap minggu ${ }^{9}$. Wanita yang dalam pekerjaannya perlu berdiri dalam waktu lama, berulangkali membungkuk dan menekuk, menaiki tanjakan atau tangga, dan mengangkat benda berat mengalami lebih banyak infark plasenta, abortus spontan, dan bayi lahir dengan berat badan rendah ${ }^{10}$. Ibu hamil yang setiap harinya tidak sibuk dengan rutinitas pekerjaan mempunyai peluang lebih banyak untuk datang memeriksakan kehamilannya dan mendapatkan informasi tentang kesehatan seputar kehamilannya. Sementara itu, untuk ibu hamil yang bekerja diluar rumah seringkali tidak mempunyai lebih banyak waktu untuk memeriksakan kehamilan sehingga mempunyai pengetahuan yang kurang ${ }^{14}$.

\section{Hubungan antara Paritas dengan Tingkat Pengetahuan tentang Tanda Bahaya Kehamilan}

Paritas adalah jumlah kehamilan yang menghasilkan janin hidup, bukan jumlah janin yang dilahirkan. Janin yang lahir hidup ataupun mati tidak dapat mempengaruhi status paritas ${ }^{6}$. Paritas ibu dalam penelitian ini dikategorikan menjadi 3 kategori yaitu nullipara, primipara, dan multipara. Jenis paritas dengan frekuensi tertinggi adalah ibu dengan paritas nullipara sejumlah 13 ibu $(40,6 \%)^{14}$.

Pengetahuan

seseorang

meru pakan hasil dari pengalaman, yaitu dipengaruhi oleh pengalaman sebelum nya dan oleh kebutuhan individu ${ }^{12}$. Pengalaman pribadi seorang ibu dapat digunakan sebagai upaya dalam memperoleh suatu pengetahuan. Hal tersebut dapat dilakukan dengan cara mengulang kembali pengalaman yang pernah diperoleh atau dialaminya dalam memecahkan persoalan yang dihadapi dalam masa yang akan datang. Pengalaman dalam melewati masa kehamilan akan berdampak terhadap pola pikir atau pandangan, sikap dan tindakan ibu pada kehamilan berikutnya ${ }^{14}$.

Hasil uji statistik antara paritas dengan tingkat pengetahuan menunjukkan nilai $p$ value $=0,049$ yang berarti signifikan karena $p$ value $<0,05$. Hal ini menunjukkan bahwa ada hubungan antara paritas ibu dengan tingkat pengetahuan tentang tanda bahaya kehamilan. Penelitan ini sesuai dengan penelitian yang pernah dilakukan oleh Sulyani (2013) yang menunjukkan bahwa ada hubungan antara paritas dengan tingkat 
pengetahuan tentang tanda bahaya kehamilan dengan nilai 0,000 $(p<0,05)^{13}$. Hasil penelitian lainnya dari Astuti (2011) juga menunjukkan ada hubungan yang signifikan ada hubungan antara paritas dengan tingkat pengetahuan tentang tanda bahaya kehamilan dengan nilai $0,040(p<0,05)^{2}$.

Hal ini tidak sesuai dengan penelitian Sukesih (2012) di wilayah Puskesmas Tegal yang menunjukkan tidak ditemukan adanya hubungan yang bermakna antara pengalaman dengan pengetahuan ibu. Sholihah (2007) di Kabupaten Garut juga menunjukkan bahwa pengalaman mempunyai anak (paritas) tidak berhubungan dengan pengetahuan tentang tanda bahaya pada kehamilan ${ }^{12}$.

Hasil penelitian menunjukkan adanya paritas multipara yang memiliki tingkat pengetahuan kurang yaitu sebanyak 6 ibu $(18,8 \%)$. Hal tersebut bisa terjadi karena seiring dengan bertambahnya jumlah anak yang dimiliki oleh seorang ibu, maka akan semakin banyak juga waktu dan perhatian ibu yang tersita untuk mengurus, mendidik dan membesarkan anak-anaknya. Sehingga ibu tidak memiliki waktu yang cukup luang untuk menambah pengetahuan dan pada akhirnya akan berpengaruh pada sikap ataupun pengetahuan ibu dalam mengetahui tanda-tanda bahaya kehamilan. Hal tersebut berbeda dengan ibu yang belum memiliki anak yang pastinya mempunyai waktu dan kesempatan lebih banyak untuk menambah pengetahuan dan wawasannya mengenai tanda bahaya kehamilan sehingga diharapkan sikap dan pengetahuan ibu dalam mengenal tanda bahaya kehamilan semakin baik ${ }^{5}$.

\section{Hubungan antara Riwayat Kunjungan ANC dengan Tingkat Pengetahuan tentang Tanda Bahaya Kehamilan}

ANC atau pemeriksaan kehami lan merupakan pemeriksaan ibu hamil baik fisik dan mental serta menyelamatkan ibu dan anak dalam kehamilan, persalinan dan masa nifas, sehingga keadaan mereka post partum sehat dan normal ${ }^{17,24}$. Kunjungan antenatal care adalah kunjungan ibu hamil ke bidan atau dokter sedini mungkin semenjak wanita merasa dirinya hamil untuk mendapatkan pelayanan/asuhan antenatal $^{7,14}$. Pada kunjungan ANC, pelayanan terhadap individu bersifat preventif care untuk mencegah terjadinya masalah yang kurang baik bagi ibu maupun janin. ANC merupakan upaya kesehatan perorangan yang memperhatikan ketelitian dan kualitas pelayanan medis yang diberikan, agar dapat melalui persalinan dengan sehat dan aman diperlukan kesiapan fisik dan mental ibu, sehingga ibu dalam keadaan status kesehatan yang optimal' ${ }^{14}$.

Dalam penelitian ini yang dimaksud dengan riwayat kunjungan ANC adalah riwayat kunjungan ibu saat hamil dengan tenaga kesehatan untuk mendapatkan pelayanan ANC. Riwayat kunjungan ANC dinilai berdasarkan pertanyaan dalam kuesioner dan catatan buku KIA ibu. Kunjungan ANC dinilai baik apabila berjumlah minimal 4 kali selama kehamilan (1 kali pada TM 1, 1 kali pada TM 2, 2 kali pada TM 3). Riwayat kunjungan ANC dibagi menjadi dua, yaitu terpenuhi dan 
tidak terpenuhi. Frekuensi riwayat kunjungan ANC tertinggi yaitu pada kategori terpenuhi sebanyak 28 ibu (87,5\%). Hasil uji statistik antara riwayat kunjungan ANC dengan tingkat pengetahuan menunjukkan nilai $p$ value $=0,007$ yang berarti signifikan karena $p$ value $<0,05$. Hal ini menunjukkan bahwa ada hubungan antara riwayat kunjungan ANC ibu dengan tingkat pengetahuan tentang tanda bahaya kehamilan. Didalam kunjungan ANC terdapat konseling, sehingga dapat digunakan untuk memberikan informasi mengenati tanda bahaya kehamilan pada setiap kunjungan ANC. Semakin sering ibu hamil mendapatkan informasi maka akan semakin meningkat pengetahuan ibu hamil mengenai tanda bahaya kehamilan ${ }^{1}$.

Hal tersebut sesuai dengan penelitian yang dilakukan oleh Kartika (2012) yang menunjukkan hasil ada hubungan yang signifikan antara pengetahuan ibu hamil tentang tanda bahaya kehamilan dengan kepatuhan melakukan ANC dengan nilai $0,005 \quad(p<0,05)^{7}$. Penelitian ini juga sejalan dengan penelitian Sembiring (2013) dan Kamidah (2013) yang menghasilkan bahwa ada hubungan antara kepatuhan kunjungan ANC dengan tingkat pengetahuan ibu hamil tentang tanda bahaya kehamilan ${ }^{6,10}$. Semakin terpenuhi riwayat kunjungan ANC maka semakin baik pula tingkat pengetahuan?. Sehingga kemungkinan ibu hamil untuk patuh melakukan kunjungan ANC akan semakin besar. Ibu hamil akan semakin ingin memeriksakan kehamilannya secara teratur atau patuh kepada petugas kesehatan khususnya bidan selam periode kehamilannya ${ }^{10}$.
Pemeriksaan kehamilan (ANC) ini merupakan salah satu program yang terencana berupa observasi, edukasi, dan penanganan medik pada ibu hamil untuk memperoleh suatu proses kehamilan dan persalinan yang aman dan memuaskan. Tujuan utamanya adalah menurunkan atau mencegah kesakitan dan kematian maternal dan perinatal. Tujuan tersebut akan tercapai apabila ibu hamil patuh dalam melakukan pemeriksaan kehamilan. Secara deskriptif, penelitian ini menggambarkan bahwa ibu hamil yang sebagian besar dikategorikan patuh dalam melaksanakan kunjungan ANC sebanding dengan pengetahuan mereka yang sebagian besar dikategorikan baik ${ }^{6}$. Ibu hamil yang tidak memeriksakan kehamilannya secara teratur menyebabkan tidak terdeteksinya tanda bahaya dan komplikasi yang terjadi pada saat hamil atau pada saat persalinan yang akan mengancam kesehatan dirinya dan janin yang dikandungnya ${ }^{14}$. Dampak dari ketidakpatuhan ibu dalam kunjungan ANC adalah ibu hamil akan kurang mendapatkan informasi tentang cara perawatan kehamilan yang benar, tidak terdeteksinya penyakit dan komplikasi selama kehamilan. Sehingga apabila tidak ditangani akan mengakibatkan komplikasi pada saat kehamilan ataupun persalinan dan akan mengarah pada kematian ibu? ${ }^{7}$.

\section{Hubungan antara Dukungan Suami dengan Tingkat Pengetahuan tentang Tanda Bahaya Kehamilan}

Dukungan suami pada saat kehamilan adalah segala sesuatu 
yang diperbuat suami dalam merespon kehamilan istrinya ${ }^{11}$. Dukungan suami menghasilkan suatu peranan yang penting dalam kesehatan selama masa kehamilan karena memberikan suatu hubungan ataupun dukungan sosial yang baik untuk meningkatkan kesehatan ibu hamil ${ }^{12}$.

Dukungan suami pada saat kehamilan adalah segala sesuatu yang diperbuat suami dalam merespon kehamilan istrinya dalam bentuk interaksi dimana ada hubungan saling mengasihi dan mendapatkan bantuan yang nyata dilakukan oleh seorang suami terhadap istrinya. Suami merupakan orang yang paling dekat dengan ibu dan memiliki banyak peran selama ibu menjalani masa kehamilan, persalinan, sampai nifas. Respon suami yang baik terhadap kehamilan istrinya merupakan sebuah perilaku positif yang dapat menyebabkan adanya rasa percaya diri, ketenangan batin dan pikiran positif. Wanita yang dijaga, diperhatikan, dilindungi,dan dikasihi oleh suaminya selama hamil akan mempunyai emosional yang stabil, kemungkinan terjadinya komplikasi persalinan berkurang, dan lebih mudah beradaptasi ${ }^{12}$.

Suami dapat memberikan dukungan dengan mengerti dan memahami setiap perubahan yang terjadi pada istrinya, memberikan perhatian dengan penuh kasih sayang dan berusaha untuk meringankan beban kerja istri. Dukungan suami yang didapatkan calon ibu akan menimbulkan perasaan tenang, sikap positif terhadap diri sendiri dan kehamilannya, maka diharapkan ibu dapat menjaga kehamilannya dengan baik sampai saat persalinan ${ }^{11}$.

Data frekuensi dukungan suami tertinggi yaitu dukungan suami baik sebanyak 26 ibu $(81,2 \%)$ dan frekuensi terendah pada dukungan suami sedang sebanyak 6 ibu (18.8\%). Dukungan suami masuk didalam lingkup dukungan sosial, dimana yang dimaksud dari dukungan sosial adalah bentuk dukungan dan hubungan yang baik untuk memberikan kontribusi penting pada kesehatan. Hal tersebut akan membuat orang merasa diperhatikan, dicintai, dimuliakan dan dihargai ${ }^{4}$.

Hasil uji statistik antara dukungan suami dengan tingkat pengetahuan menunjukkan nilai $p$ value $=0,007$ yang berarti signifikan karena $p$ value $<0,05$. Hal ini menunjukkan bahwa ada hubungan antara dukungan suami dengan tingkat pengetahuan tentang tanda bahaya kehamilan. Respon suami terhadap kehamilan istri yang dapat menyebabkan adanya ketenangan batin dan perasaan senang dalam istri. Wanita yang diperhatikan dan dikasihi oleh pasangan prianya selama hamil akan menunjukkan lebih sedikit gejala emosi dan fisik, lebih sedikit komplikasi persalinan, dan lebih mudah melakukan penyesuaian selama nifas ${ }^{11}$.

Adanya dukungan atau motivasi dari suami berperan sangat besar dalam menentukan status kesehatan dan tingkat pengetahuan ibu dalam mengetahui tanda-tanda bahaya kehamilan. Jika suami mengharapkan adanya kehamilan, maka akan memperlihatkan dukungannya dalam berbagai hal yang dapat mempengaruhi ibu menjadi lebih percaya diri, lebih berbahagia, menunjukkan kesiapan 
dan lebih kuat secara mental untuk menghadapi segala hal selama masa kehamilan tersebut. Keterlibatan anggota keluarga atau orang terdekat terutama pasangan/suami dapat membantu terjadinya perubahan untuk berperilaku dan juga meningkatkan kesadaran untuk berubah ke arah hidup sehat. Oleh karena itu, suami memiliki peranan yang sangat penting untuk memberikan berbagai jenis dukungan pada ibu supaya ibu merasa lebih nyaman dalam menjalani masa kehamilan dan meminimalkan resiko timbulnya tanda-tanda bahaya kehamilan ${ }^{15}$.

Suami dapat memberikan dukungan dengan mengerti dan memahami setiap perubahan yang terjadi pada istrinya, memberikan perhatian dengan penuh kasih sayang dan berusaha untuk meringankan beban kerja istri. Dukungan suami yang didapatkan calon ibu akan menimbulkan perasaan tenang, sikap positif terhadap diri sendiri dan kehamilannya, maka diharapkan ibu dapat menjaga kehamilannya dengan baik sampai saat persalinan ${ }^{16}$.

\section{SIMPULAN}

Pada karakteristik ibu, sebagian besar usia ibu dalam kategori usia reproduksi sehat sebanyak 23 ibu $(71,9 \%)$, sebagian besar mempunyai tingkat pendidikan yang tinggi sebanyak 20 ibu $(62,5 \%)$, sebagian besar ibu tidak bekerja yaitu sebanyak 18 ibu $(56,2 \%)$, paritas paling banyak pada paritas nullipara sejumlah 13 ibu $(40,6 \%)$, dan riwayat kunjungan ANC tertinggi yaitu pada kategori terpenuhi sebanyak 28 ibu (87,5\%). Sebagian besar ibu memiliki dukungan suami yang baik sebanyak 26 ibu (81,2\%). Sebagian besar ibu memiliki kategori tingkat pengetahuan baik sebanyak 14 ibu $(43,8 \%)$.

Terdapat hubungan antara usia $(0,000 ; p<0,05)$, pendidikan $(0,037 ; p<0,05)$, pekerjaan $(0,028$; $p<0,05)$, paritas $(0,049 ; \quad p<0,05)$, riwayat kunjungan ANC $(0,007$; $\mathrm{p}<0,05) \quad$ dengan tingkat pengetahuan ibu tentang tanda bahaya kehamilan. Serta terdapat hubungan antara dukungan suami dengan tingkat pengetahuan tentang tanda bahaya kehamilan dengan $p$ value 0,007 ( $p<0,05)$.

\section{DAFTAR PUSTAKA}

\section{REFERENSI}

1. Kemenkes. 2014. Peningkatan Kesehatan Ibu dan Anak. Jakarta: Pusat Promosi Kesehatan Kementerian Kesehatan Republik Indonesia. http://promkes. depkes.go.id/dl/lembar\%20balik\%2 Oposkesdes.pdf.

2. Kemenkes. $2014 . \quad$ Situasi Kesehatan Ibu. Jakarta: Pusat Data dan Informasi - Kementerian Kesehatan Republik Indonesia. http://www.depkes.go.id/ folder/view/01/structure-publikasipusdatin-info-datin.html

3. Kemenkes. 2010. Pedoman Pelayanan Antenatal Terpadu. Jakarta: Direktorat Jenderal Bina Kesehatan Masyarakat Kementerian Kesehatan Republik Indonesia.

http://perpustakaan.depkes.go.id:81 80/bitstream//123456789/202 4/2/BK2010-456.pdf

4. Kemenkes. 2010. Pedoman Pemantauan Wilayah Setempat Kesehatan Ibu Dan Anak (PWS$K I A)$. Jakarta: Direktorat Jenderal 
Bina Kesehatan Masyarakat \& Direktorat Bina Kesehatan lbu Kementerian Kesehatan Republik Indonesia.

http://www.gizikia.depkes.go.id/wpcontent/uploads/downloads/2013/08 Pedo man-PWS-KIA.pdf.

5. Kemenkes. 2013. Buku Saku Pelayanan Kesehatan lbu di Fasilitas Kesehatan Dasar dan Rujukan. Jakarta: Kementerian Kesehatan Republik Indonesia. http://www.gizikia.depkes.go.id/wpcontent/uploads/downloads/2013/12 /Buku -Saku-Pelayanan-Kesehatanlbu.pdf

6. Kemenkes. 2013. Profil Kesehatan Indonesia $2012 . \quad$ Jakarta: Kementerian Kesehatan Republik Indonesia.

http://www.depkes.go.id/resources/ download/ pusdatin/profilkesehatan-indonesia/profilkesehatan-indonesia-2012.pdf

7. Agustini, S. 2012. Pengetahuan Ibu Hamil tentang Tanda-Tanda Bahaya Kehamilan di Wilayah Kerja UPT Puskesmas Cimandala Kecamatan Sukaraja Kabupaten Bogor Tahun 2012. Skripsi. Diterbitkan, Fakultas Kesehatan Masyarakat Universitas Indonesia, Depok.

lib.ui.ac.id/file?file=digital/20314706 -S Sri\%20Agustini.pdf

8. Pembe, Andrea B., Urasso, D.P., Carlsted, A., Lindmark, G., Nystrapq, L., Darj. 2011. Rural Tanzanian Women's Awarness of DANGER Sign of Obstetric Complication. Basic data Proquest health and medicine complete

9. Kartika, E.Y. 2012. Hubungan Pengetahuan lbu Hamil Trimester III tentang Tanda Bahaya Kehamilan dengan Kepatuhan ANC di wilayah Kerja Puskesmas Lerep Kecamatan Ungaran. Semarang: Akademi Kebidanan Ngudi Waluyo

10. Meko, M.Y.D. 2012. Faktor-Faktor yang Berhubungan dengan Pengetahuan Suami tentang Tanda
Bahaya pada Masa Kehamilan, Persalinan dan Nifas di Wilayah Kerja Puskesmas Bakunase tahun 2011. Kupang: FKM Undana

11. Widiantari, N.K.N. 2015. Hubungan Karakteristik lbu dan Dukungan Sosial Suami Dengan Partisipasi Ibu Mengi kuti Kelas Ibu Hamil Di Kota Denpasar. Tesis. Diterbitkan, Magister IImu Kesehatan Masyarakat, Universitas Udayana, Denpasar. http://www.pps. unud.ac.id/thesis/pdf thesis/unud152 3-77867673tesis\%20\%20nopi\%20\% 20fix.pdf

12. Sulyani, P. 2013. Hubungan Karakte ristik lbu Hamil dengan Pengetahuan lbu Hamil terhadap Tanda-Tanda Bahaya Kehamilan di Puskesmas Bandar Kabupaten Bener Meriah. Banda Aceh: Stikes Ubudiyah

13. Astuti, H.P. 2011. Hubungan Karakteristik Ibu Hamil dengan Tingkat Pengetahuan tentang Tanda Bahaya pada Kehamilan di Puskesmas Sidoharjo Kabupaten Sragen. Jurnal Stikes Kusuma Husada Surakarta, hal. 1-13. http://digilib.stikeskusumahusa da.ac.id/files/disk1/3/01-gdltriwulanda - 119-1-tri wula-i.pdf

14. Sukesih. 2012. Faktor-Faktor yang Berhubungan dengan Pengetahuan Ibu Hamil Mengenai Tanda Bahaya dalam Kehamilan di Puskesmas Tegal Selatan Kota Tegal Tahun 2012. Skripsi. Diterbitkan, Fakultas Keseha tan Masyarakat Universitas Indonesia, Depok. lib.ui.ac.id/file?file=digital/203 15113-S Sri\%20Sukesih.pdf

15. Wulandari, R. 2014. Hubungan Tingkat Pendidikan Ibu Hamil dengan Pengetahuan Tanda Bahaya Kehami lan pada Trimester III di RB Harapan Bunda Surakarta. Surakarta: STIK PKU Muhammadiyah. http://digilib. stikespku.ac. id/ download.php?id=76. 